\title{
Double-stranded DNA of Soybean Chlorotic Mottle Virus
}

\author{
Tadaaki HibI*, Mitsuro IwAKI**, Yasuo SAITo**, \\ Jan VERVER*** and Rob GoldBACH***
}

\begin{abstract}
The nucleic acid of soybean chlorotic mottle virus (SoyCMV) was isolated and analysed. $\mathrm{CsCl}$ equilibrium density gradient centrifugation and thermal denaturation kinetics revealed that the nucleic acid is a double-stranded DNA. Electrophoresis in agarose gels separated SoyCMV DNA into multiple bands, similar to those of cauliflower mosaic virus (CaMV) DNA, which indicated that this DNA consisted of both linear and circular molecules. The existence of these different topological forms was confirmed by electron microscopy. Using six different restriction endonucleases a physical map was constructed which showed the SoyCMV genome to be a circular DNA molecule of approximately 8,200 base pairs long. The results obtained support the previous assignment of SoyCMV to the caulimovirus group.
\end{abstract}

(Received June 3, 1986)

Key words: SoyCMV, caulimovirus, DNA, physical mapping.

\section{Introduction}

Recently, a new disease of soybean, named soybean chlorotic mottle, has been detected in Japan ${ }^{7}$. The pathogen was found to be a virus, denoted soybean chlorotic mottle virus (SoyCMV), which consisted of spherical particles with a diameter of approximately 50 $\mathrm{nm}$ and which could be transmitted by mechanical inoculation, but not by aphids, to four different Leguminosae species. Characteristic symptoms included chlorotic mottling and stunting of the plants.

Although SoyCMV is serologically not related to cauliflower mosaic virus (CaMV) or carnation etched ring virus (CERV), the virus is considered to be a new member of the caulimovirus group on the basis of its particle structure and the formation of cytoplasmic inclusion bodies" ${ }^{7}$. By analytical ultracentrifugation, thermal denaturation kinetics, electron microscopy and electrophoretical analysis, we now demonstrate that SoyCMV contains a circular, double-stranded DNA. In addition, we have determined the cleavage sites for six different restriction endonucleases. The resulting physical map confirms that SoyCMV DNA is circular, with a size of approximately 8,200 base pairs.

*Laboratory of Applied Microbiology, National Institute of Agrobiological Resources, Tsukuba Science City, Ibaraki 305，Japan 農林水産省農業生物資源研究所

** Division of Microbiology, National Institute of Agro-Environmental Sciences, Tsukuba Science City, Ibaraki 305, Japan (Y. Saito: Present address; Food and Fertilizer Technology Center for the Asian and Pacific Region, Agriculture Building, 14 Wen Chow Street, Taipei, Taiwan) 農 林水産省農業環境技術研究所

*** Department of Molecular Biology, Agricultural University, De Dreijen 11, 6703 BC Wageningen, The Netherlands. 


\section{Materials and Methods}

Preparation of virus and extraction of virus nucleic acid. SoyCMV was propagated in bean leaves (Phaseolus vulgaris cv. Kintoki). 20 days after mechanical inoculation the virus was purified from leaf material according to the procedure for CaMV $^{5)}$ and modified as described previously"). Nucleic acid was extracted from purified virus by the method for CaMV $\mathrm{DNA}^{12)}$, except that $1 \mathrm{mg} / \mathrm{ml}$ of proteinase $\mathrm{K}$ instead of pronase was used in the presence of $1 \%$ SDS. CaMV DNA, used as reference, was similarly prepared from purified CaMV.

Equilibrium density gradient centrifugation. Equilibrium density gradient centrifugation was performed according to the method of Vinograd and Hearst ${ }^{14)}$. Nucleic acid (final concentration, about $0.7 \mu \mathrm{g} / \mathrm{ml}$ ) was mixed with $\mathrm{CsCl}$ (initial density, 1.704 $\mathrm{g} / \mathrm{cm}^{3}$ ) in $0.01 \mathrm{M}$ Tris- $\mathrm{HCl}$ buffer, $\mathrm{pH} 8.5$, containing $1 \mathrm{mM}$ EDTA and centrifuged for $48 \mathrm{hr}$ at $44,000 \mathrm{rpm}$ and $25 \mathrm{C}$ using MSE Centriscan 75 analytical ultracentrifuge equipped with ultraviolet optics.

Thermal denaturation. Thermal denaturation kinetics of SoyCMV DNA in $1 \times$ SSC ( $0.15 \mathrm{M} \mathrm{NaCl}, 0.015 \mathrm{M} \mathrm{Na}$ citrate, $\mathrm{pH}$ 7.0) was followed by determining the rate of increase in absorbance at $260 \mathrm{~nm}$ in a thermal block of a Gilford 2400 S spectrophotometer equipped with a Gilford 2527 thermoprogrammer set at a heating rate of $0.50 \mathrm{C} / \mathrm{min}$ from 30 to $100 \mathrm{C}$.

Electron microscopy of nucleic acid. SoyCMV DNA was prepared for electron microscopy by the benzyldimethylalkylammonium chloride (BAC)-droplet method ${ }^{15)}$ from a solution containing $0.4 \mu \mathrm{g} / \mathrm{ml}$ of DNA, $2 \times 10^{-4} \% \mathrm{BAC}, 40 \%$ formamide and $12 \mathrm{mM}$ triethanolamine, $\mathrm{pH} 7.4$, stained with $1 \mathrm{mM}$ uranyl acetate and shadowed with platinumpalladium. The specimens were examined in a Hitachi $H 500$ electron microscope and photographed at a magnification of $14,100 \times$. Phage $\phi X 174$ RF-DNA was used as an internal standard. Negatives were enlarged 9 times and molecular lengths were measured with a Numonics electronic graphics calculator.

Infectivity assay of nucleic acid. Aliquots of SoyCMV DNA solutions in 1X SSC were mechanically inoculated on each of both primary leaves (100 $\mu$ l per leaf) of five bean seedlings at concentrations of 4,20 or $100 \mu \mathrm{g} / \mathrm{ml}$, respectively, by rubbing the leaves, previously dusted with Carborundum, with a cotton piece soaked in inoculum. The inoculated plants were grown in a glasshouse and development of symptoms were examined 47 days after inoculation.

Restriction endonuclease treatment and gel electrophoresis. Restriction endonucleases, SacI and SalI (from Boehringer Mannheim GmbH) and AccI, BglII, PvuII and ScaI (from New England Biolabs) were used according to the manufacturer's instructions. Restriction endonuclease digests or untreated DNA were analysed in horizontal agarose slab gels in Tris-acetate buffer ( $40 \mathrm{mM}$ Tris-HCl, $1 \mathrm{mM}$ EDTA, $5 \mathrm{mM}$ sodium acetate, $\mathrm{pH} 7.8$ ) or, alternatively, in Tris-borate buffer $(89 \mathrm{mM}$ Tris, $89 \mathrm{mM}$ borate, $2.5 \mathrm{mM}$ EDTA, $\mathrm{pH}$ 8.3) under submarine conditions. HindIII and EcoRI endonuclease fragments of $E$. coli $\lambda$ phage DNA were used as molecular weight markers. DNA bands were visualised by staining in ethidium bromide. 


\section{Results}

\section{Buoyant density and thermal denaturation kinetics of SoyCMV DNA}

The buoyant density of SoyCMV nucleic acid in $\mathrm{CsCl}$ was estimated to be $1.688 \mathrm{~g} /$ $\mathrm{cm}^{3}$ (Fig. 1), indicating it to be double-stranded DNA rather than RNA. From this density a GC content of $28.0 \%$ can be deduced ${ }^{2}$. Upon thermal denaturation in $1 \times \mathrm{SSC}$ SoyCMV nucleic acid showed a sharp melting transition with a hyperchromicity of 38.4

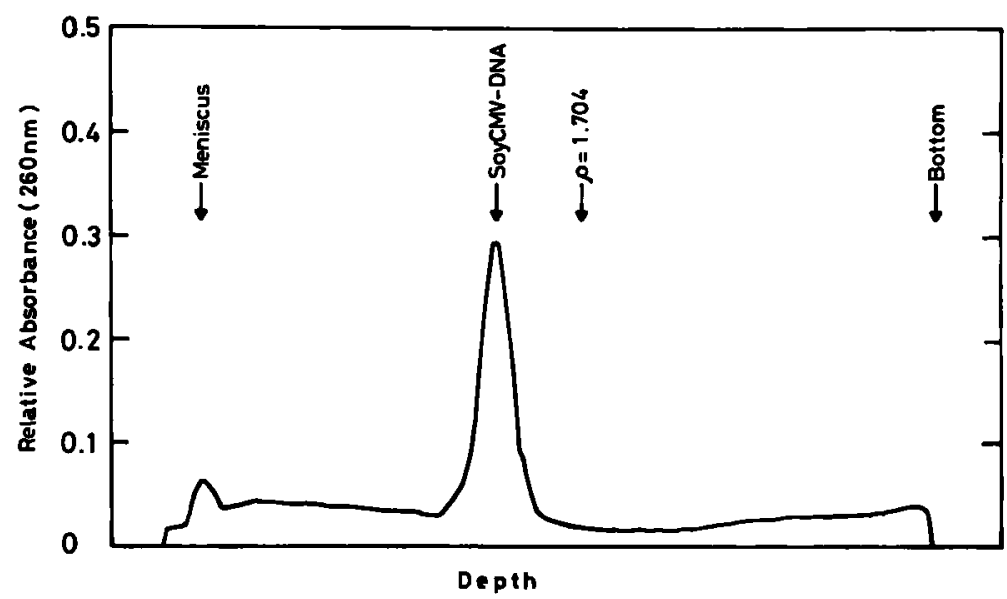

Fig. 1. Optical density profile of SoyCMV DNA upon equilibrium density gradient centrifugation in $\mathrm{CsCl}$. The DNA was mixed with $\mathrm{CsCl}$ in $0.01 \mathrm{M}$ Tris- $\mathrm{HCl}$ buffer ( $\mathrm{pH} 8.5$ ) containing $1 \mathrm{mM}$ EDTA to produce a solution of density 1.704 $\mathrm{g} / \mathrm{cm}^{3}$. The sample was centrifuged at $44,000 \mathrm{rpm}$ for $48 \mathrm{hrs}$ at $25 \mathrm{C}$ in an analytical ultracentrifuge and the optical density profile was measured at 260 nm.

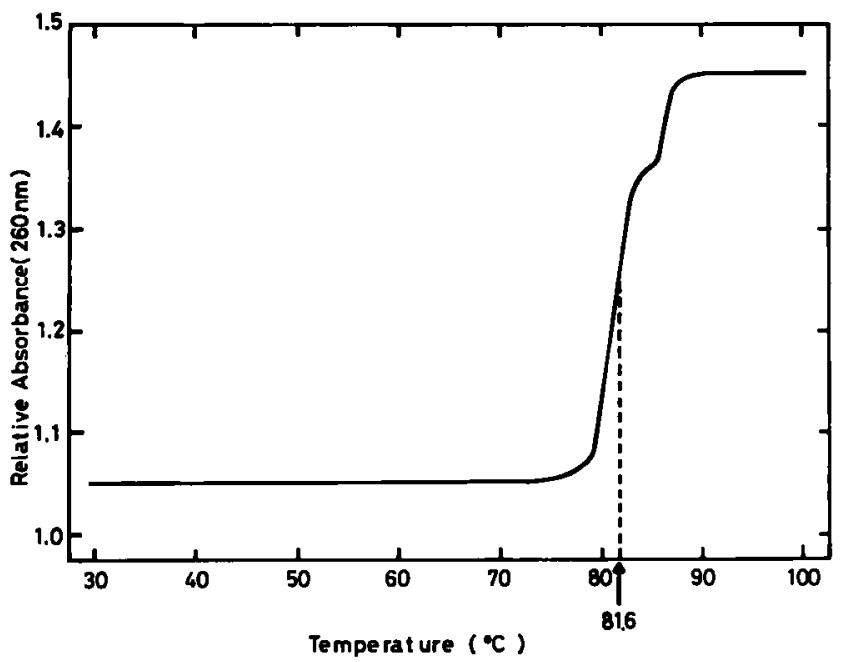

Fig. 2. Thermal denaturation kinetics of SoyCMV DNA. Approximately $70 \mu \mathrm{g} / \mathrm{ml}$ of DNA was suspended in $1 \times$ SSC and the increase in absorbance at $260 \mathrm{~nm}$ was followed at a heating rate of $0.50 \mathrm{C}$ per minute. 
$\%$ (Fig. 2) indicating once more that the SoyCMV genome consisted of double-stranded DNA. The DNA melted at a Tm of $81.6 \mathrm{C}$, corresponding to a GC content of $30.0 \% \%^{9}$, a value which agrees rather well with the estimate from the $\mathrm{CsCl}$ centrifugation. Under the same conditions ( $1 \times \mathrm{SSC})$, the Tm and GC content of CaMV DNA have been estimated to be $87.2 \mathrm{C}$ and $43.5 \%$, respectively ${ }^{12)}$.

\section{Gel electrophoresis of native $D N A$.}

Electrophoresis of SoyCMV DNA preparations in $1 \%$ agarose gels resulted in the resolution of several distinct bands, similar and almost comigrating with those of CaMV DNA (Fig. 3 and 5). It has been reported that the multiple bands of CaMV DNA represent different topological forms and that under similar electrophoretic conditions as used here the fastest migrating band contained linear molecules while the others contained circular molecules ${ }^{6}$. This, togather with the migration of bands formed by DNA cut at a single site by restriction endonucleases (see below), indicates that the fastest migrating band of SoyCMV DNA also contains linear molecules, with an approximate size of 8,200 base pairs, while the slower migrating bands represent circular forms.
(1) (2)

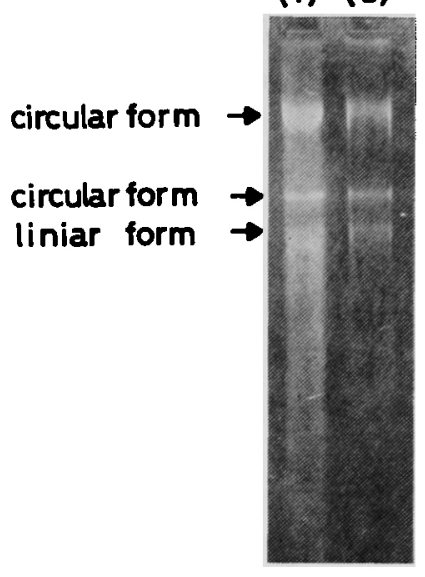

Fig. 3. Electrophoresis in a $1 \%$ agarose gel of native DNA of SoyCMV (lane 1) and CaMV (lane 2), using Tris-borate buffer.

\section{Electron microscopy of SoyCMV DNA}

Electron microscopical analysis of native, unfractionated SoyCMV DNA confirmed the

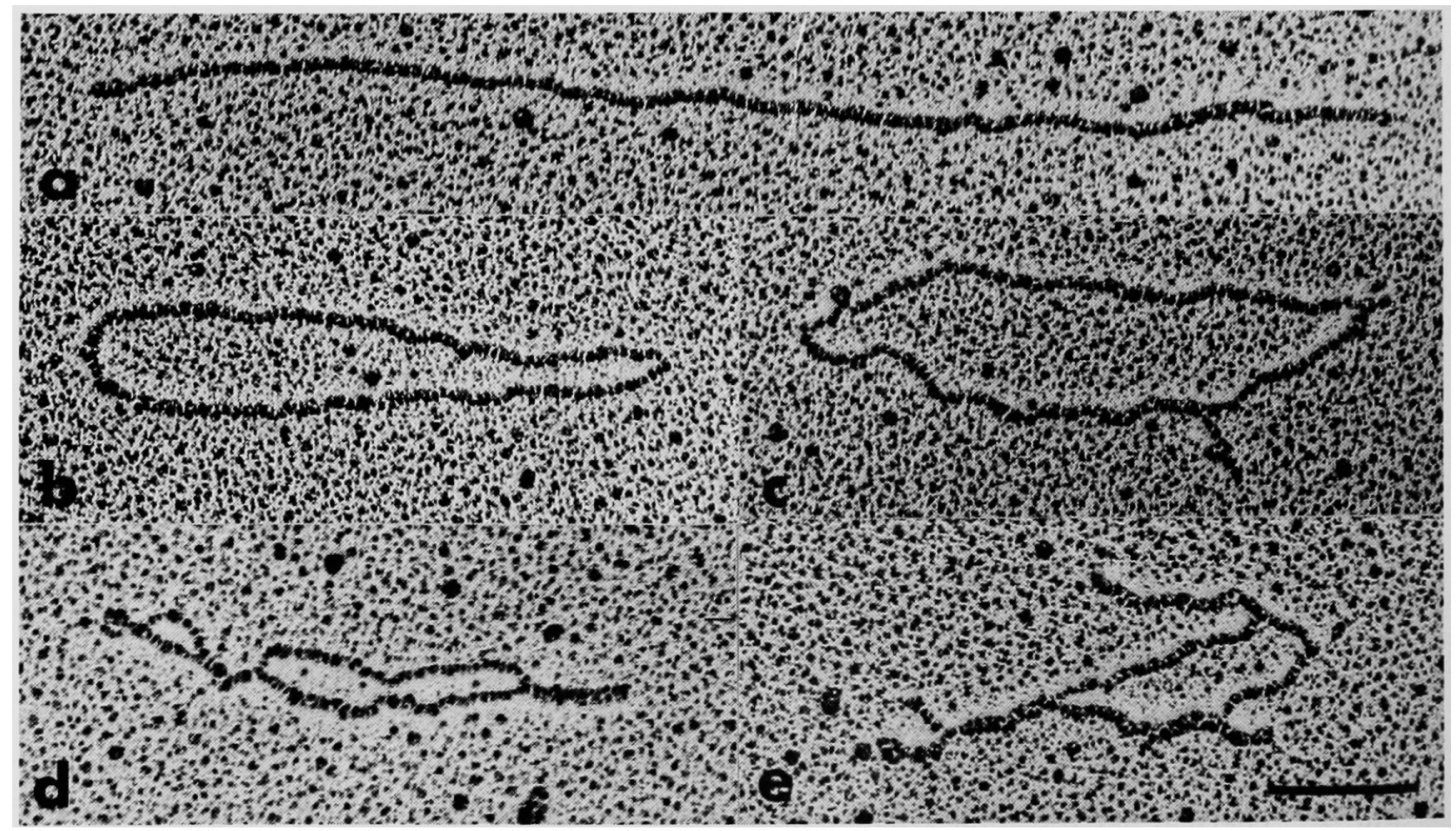

Fig. 4. Electron micrographs of linear (a), relaxed open circular (b and c) and twisted circular ( $d$ and e) molecules of SoyCMV DNA. The bar represents $200 \mathrm{~nm}$. 
presence of both linear and circular molecules (Fig. 4), similar as reported for CaMV DNA preparations ${ }^{5,11,13)}$. The circular molecules predominated over the linear ones and were composed of many highly twisted molecules and a few relaxed open circular forms. Although the length of the molecules prepared with BAC as spreading carrier were slightly shorter than those prepared with cytochrome $\mathrm{C}$, the approximate size of relaxed open circular molecules and linear molecules was for both 8 kilobase pairs (kbp) when roughly calculated on the ratio of the mean contour length of each ten molecules to those of $\phi \mathrm{X} 174 \mathrm{RF}-\mathrm{DNA}$ marker molecules.

\section{Infectivity of SoyCMV DNA}

Purified SoyCMV DNA was tested for its infectivity on bean plants, Phaseolus vulgaris cv. Kintoki, a local lesion host of the virus (Table 1). The infectivity of SoyCMV DNA appeared significantly lower than that of isolated CaMV DNA ${ }^{12}$ and to be almost the same as that of isolated CERV DNA ${ }^{8}$.

Table 1. Infectivity of extracted SoyCMV DNA a)

\begin{tabular}{c|c}
\hline $\begin{array}{c}\text { Conc. of SoyCMV DNA } \\
(\mu \mathrm{g} / \mathrm{ml})\end{array}$ & $\begin{array}{l}\text { No. of infected plants } / \\
\text { No. of inoculated plants }\end{array}$ \\
\hline 4 & $0 / 5$ \\
20 & $1 / 5$ \\
100 & $2 / 5$ \\
\hline
\end{tabular}

a) Quantities of $100 \mu 1$ of SoyCMV DNA solutions were inoculated on each of both primary leaves of five different bean plants (Phaseolus vulgaris), and development of symptoms was examined 47 days after inoculation.

Table 2. Fragment sizes of the cleavage products of SoyCMV DNA by six different restriction endonucleases

\begin{tabular}{|c|c|c|c|c|c|c|c|}
\hline \multicolumn{3}{|c|}{ Enzymes } & & \multirow{2}{*}{\multicolumn{4}{|c|}{ Fragments (kbp) }} \\
\hline 1 & 2 & 3 & & & & & \\
\hline Sac I & - & - & 8.2 & & & & \\
\hline Sal I & - & - & 8.2 & & & & \\
\hline Sac I & Sal I & - & 7.6 & 0.6 & & & \\
\hline Sal I & $S a c \mathrm{I}$ & - & 7.6 & 0.6 & & & \\
\hline$S a c \mathrm{I}$ & PvuII & - & 6.4 & 1.1 & 0.65 & & \\
\hline Sal I & $P v u \Pi$ & - & 6.4 & 1.2 & 0.55 & & \\
\hline$S a c \mathrm{I}$ & Sca I & - & 4.9 & 2.9 & 0.4 & & \\
\hline Sal I & Sca I & - & 4.3 & 2.9 & 1.0 & & \\
\hline$S a c$ I & $A c c \mathrm{I}$ & - & 3.1 & 3.3 & 1.2 & 0.6 & \\
\hline Sal I & $A c c \mathrm{I}$ & - & 3.7 & 3.3 & 1.2 & & \\
\hline Sal I & $A c c \mathrm{I}$ & $S c a$ I & 3.0 & 2.7 & 1.2 & 1.0 & 0.3 \\
\hline$S a c$ I & $B g l$ II & - & 4.4 & 3.3 & 0.45 & & \\
\hline Sal I & $B g l$ II & - & 5.0 & 2.7 & 0.45 & & \\
\hline$S a c \mathrm{I}$ & Sal I & $B g l \mathrm{II}$ & 4.4 & 2.7 & 0.6 & 0.45 & \\
\hline
\end{tabular}




\section{Construction of a physical map of SoyCMV DNA}

To confirm the circularity of the SoyCMV genome and to obtain a reliable estimate of its size a restriction endonuclease map of SoyCMV DNA was constructed. The products of restriction endonuclease digestion of SoyCMV DNA are listed in Table 2. Two single cutting enzymes were obtained, i.e. SacI and SalI. As shown in Fig. 5 each of

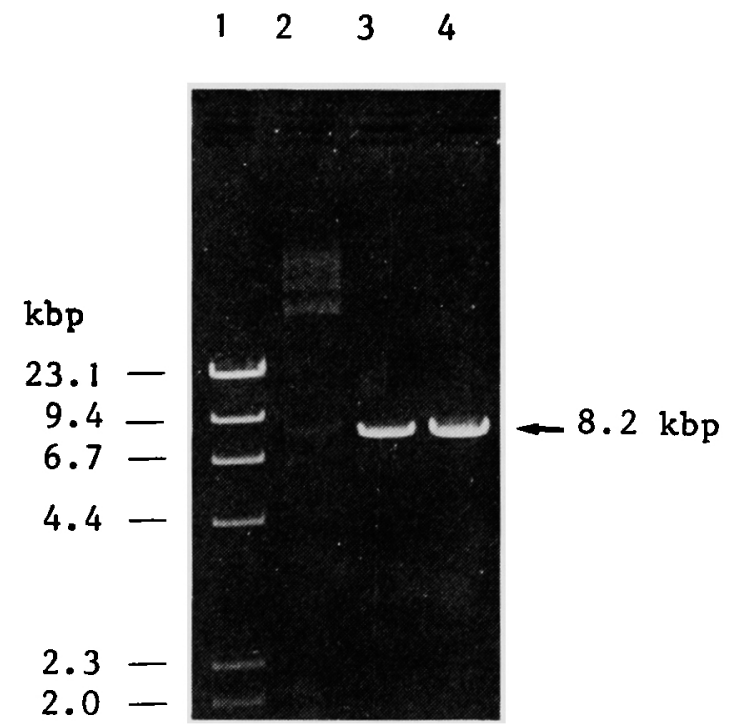

Fig. 5. Electrophoresis in a 1.1 go agarose gel of native and restriction endonuclease-cut DNA of SoyCMV, using Tris-acetate buffer. (1) Bacteriophage $\lambda$ DNA cut with HindIII ; (2) SoyCMV DNA uncut; (3) SoyCMV DNA cut with SacI ; (4) SoyCMV DNA cut with Sal I.

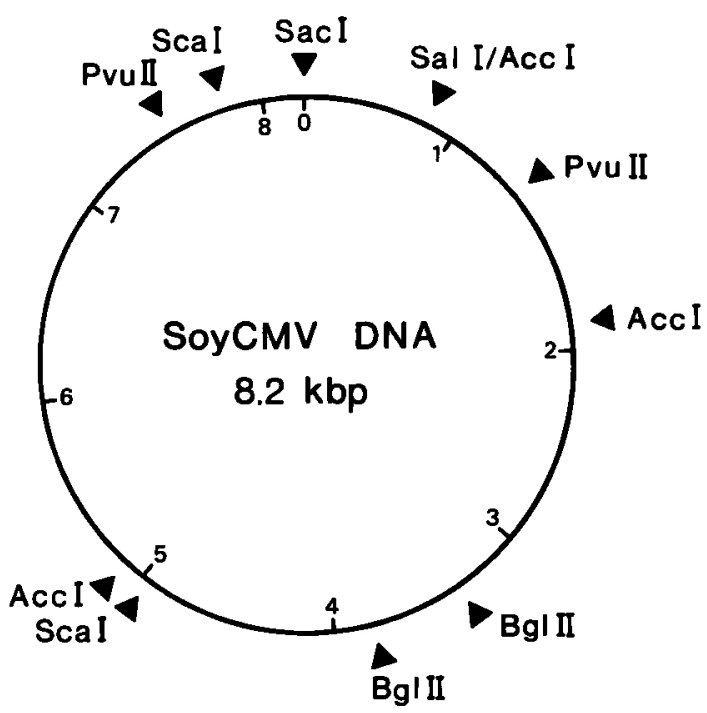

Fig. 6. The physical map of SoyCMV DNA. The cleavage sites for AccI, $B g l$ II, $P v u$ II, Sac I, Sal I and $S c a$ I are indicated. Sac I and $S a l$ I each cut at a single site. The unique Sac I site is arbitrarily chosen as zero point of the map. The numbers indicate the length in $\mathrm{kbp}$. 
these enzymes produce a single DNA band (lane 3 and 4) exactly comigrating with the fastest migrating band of uncut DNA (lane 2). This, again, indicates, that the lowest band in native DNA represents linear molecules (see also Fig. 3). Using the HindIII fragments of phage $\lambda$ DNA (Fig. 5, lane 1) as marker a size of $8.2 \mathrm{kbp}$ was calculated for the linearised molecules (Table 2). Further digestion of SacI- or SalI-linearised molecules with enzymes cutting at two (BglII, PvuII, ScaI) or three (AccI) sites resulted in an unambiguous, circular physical map of SoyCMV DNA (Fig. 6). Based on all estimates (Table 2) a definite length of $8,200 \mathrm{bp}$ could be established. Although preliminary experiments indicate that SoyCMV DNA contains single-stranded discontinuities in both strands (data not shown) these have not yet been mapped. Therefore, for the present the unique SacI site has been arbitrarily chosen as zero point of the map.

\section{Discussion}

In this paper we showed that the genome of SoyCMV consists of a double-stranded DNA molecule, having a length of approximately 8,200 base pairs. From electron microscopical analysis, electrophoretic behaviour of native DNA and the constructed restriction map, it can be deduced that the genome of SoyCMV is, in principle, circular. Preliminary results indicate the presence of several single-stranded discontinuities in native SoyCMV DNA, as has been found for other caulimoviruses. Further analyses of these discontinuities are in progress. All results support the previous assignment of this virus to the caulimovirus group, which was mainly based on morphological and biological evidence ${ }^{7}$. The restriction map of SoyCMV DNA (Fig. 6) reveales no similarities to the maps of any of the other caulimoviruses ${ }^{3,4,10)}$. This, together with the characteristic host range of the virus ${ }^{7)}$, indicates that SoyCMV is a distinct member of the group. The size of SoyCMV DNA as estimated from restriction enzyme digests (8.2 $\mathrm{kbp}$, i.e. mol. wt. $5.45 \times 10^{6}$ ) is significantly larger than that of the other caulimoviruses so far analysed $\left(7.8-8.0 \mathrm{kbp}\right.$, for a recent review see Covey $\left.{ }^{1}\right)$. It will be of great interest to study the structure and genetic properties of SoyCMV DNA in more detail and to gain more insight in the genetic basis of the important difference in host range compared to all other caulimoviruses.

We would like to thank Prof. Dr. A. van Kammen for stimulating discussion, Philip Schyns for help in the restriction enzyme experiments, Rijndert de Fluiter for art work and Gré Heitkönig and Marie-José van Neerven for typing the manuscript.

\section{Literature cited}

1. Covey, S. N. (1985). In Molecular Plant Virology, vol. II (Davies, J. W. ed.) CRC Press, Boca Raton, Florida. pp. 121-159.

2. De Ley, J. (1970). J. Bacteriology $101: 738-754$.

3. Donson, J. and Hull, R. (1983). J. gen. Virol. $64: 2281-2288$.

4. Hull, R. and Donson, J. (1982). Ibid. $60: 125-134$.

5. Hull, R. and Shepherd, R. J. (1977). Virology $79: 216-230$.

6. Hull, R. and Howell, S. H. (1978). Ibid. $86: 482-493$. 
7. Iwaki, M., Isogawa, Y., Tsuzuki, H. and Honda, Y. (1984). Plant Disease $68: 1009-1011$.

8. Lawson, R. H. and Civerolo, E. L. (1978). Phytopathology $68: 181-188$.

9. Marmur, J. and Doty, P. (1962). J. Mol. Biol. 5 : 109-118.

10. Richins, R.D. and Shepherd, R. J. (1983). J. gen. Virol. $124: 208-214$.

11. Russel, G. L., Follett, E. A. C., Subak-Shape, J. H. and Harrison, B. D. (1971). Ibid. $11: 129-138$.

12. Shepherd, R. J., Bruening, G.E. and Wakeman, R. J. (1970). Virology $41: 339-347$.

13. Shepherd, R. J. and Wakeman, R. J. (1971). Phytopathology $61: 188-193$.

14. Vinograd, J. and Hearst, J.H. (1962). Fortschr. Chem. org. Naturstoffe $20: 372-422$.

15. Vollenweider, H. J., Sogo, J. M. and Koller, Th. (1975). Proc. Nat. Acad. Sci. USA 72 : 83-87.

\section{和 文 摘 要}

日比忠明・岩木満朗・斎漛康夫・Jan VERVER・Rob GoLDBACH：ダイズ退緑斑紋ウイルスの 2 本銷 DNA の性状

ダイズ退緑斑紋ウイルス（SoyCMV) より核酸を抽出し, その理化学的性状を解析した。その結果, 塩化せ シゥム平衡密度勾配遠心による分析および熱变性曲線の測定によって, SoyCMV の核酸は 2 本鎖 DNA であ ることが明らかにされた。また, アガロースゲル電気泳動による分析と電顕観察の結果から，てのウイルス DNA には線状分子と環状分子があることが認められた。さらに，6種類の制限醉素を用いて制限醉素地图を 作成したととろ, SoyCMV のゲ/ムは約8，200塩基対から成る1分子の環状 DNA であることが示された。 以上の結果から SoyCMV は caulimovirus グループに属する新たなウイルスであることが確認された。 